\title{
DIAGNOSA DINI PADA INFEKSI HIV TIPE 1 DENGAN MENGGUNAKAN TES DOUBLE-DETECT PROTEIN
}

\author{
Crisdina Suseno ${ }^{1}$, Carlo Prawira Azali ${ }^{2}$, Reynaldo Rahima Putra ${ }^{2}$, Malinda Meinapuri ${ }^{3}$
}

\begin{abstract}
Abstrak
Tujuan yang ingin dicapai dalam penulisan gagasan tertulis ini adalah menjelaskan kajian biologi molekuler, imunologi dan aspek genetik pada infeksi HIV-1 serta memaparkan diagnosa yang efektif untuk mengetahui infeksi HIV-1 yang dapat diterapkan. Pengumpulan data dan informasi didapatkan melalui buku dan jurnal-jurnal ilmiah hasil penelitian. Data dan informasi yang diverifikasikan lebih lanjut terbatas pada bukti yang menunjukkan jenis-jenis diagnosa HIV-1 dan membuat jenis diagnosa yang lebih efektif. Setelah semua data yang dibutuhkan terkumpul, dilakukan pengelolaan data dengan menyusun secara sistematis dan logis. Tes Double-detect Protein kemungkinan memiliki keefektifan lebih tinggi dari tes yang mendeteksi antigen p24 ataupun tes yang mendeteksi antibodi. Diagnosa dini pada infeksi HIV merupakan diagnosa yang dapat membantu pendeteksian HIV pada fase awal infeksi hingga sebelum masuknya fase serokonversi. Pada saat inilah tes Double-Detect Protein dapat dilakukan. Namun, perlu dilakukan tes NASBA sebagai follow up test.
\end{abstract}

Kata kunci: HIV-1, CD4+, NASBA, rapid tes, antigen p24

\begin{abstract}
The objectives of this writing were to explain the topic of molecular biology, immunology, and the genetic aspect of HIV infection type I. And also to give out a more effective diagnose of HIV type I that can be applied. The data and information were collected from various books and scientific journals resulted from research. Data and information was verified further limited to the evidence that shows the types of diagnoses of HIV-1 and created a more effective type of diagnoses. Once all the required data collected, data management was done by arranging a systematic and logical manner. The Protein Double-Detect test had the possibility of having a higher effectiveness compared to p24 antigen test or antibody detection tests. Early diagnosis of HIV infection is a diagnosis that can help the detection of HIV in the early phase of infection prior to the entry phase of seroconversion. At this time Double-Detect Proteins Test can be done. However, NASBA tests needed as a follow-up test.
\end{abstract}

Keywords: HIV-1, CD4 +, NASBA, rapid tests, p24 antigen

Afiliasi Penulis:1. Finalis 10 Besar Gagasan Tertulis MedJonson Competition Universitas Muhamadiyah Yogyakarta 10-13 April 2014. 2. Mahasiswa Pendidikan Dokter Fakultas Kedokteran Universitas Andalas 2013. 3. Bagian Histologi Fakultas Kedokteran Universitas Andalas. Korespondensi: Crisdina Suseno, Fakultas Kedokteran Universitas Andalas Pendidikan Dokter 2013, Email: cris.crisdinasuseno@gmail.com, Telp/HP: 087792751295 


\section{PENDAHULUAN}

Sexual Transmitted Disease (STD) atau yang lebih dikenal dengan penyakit menular seksual (PMS) adalah penyakit infeksi yang ditularkan melalui hubungan seksual. Sebagian besar PMS dapat ditularkan melalui hubungan seksual antara penis, vagina, anus dan/atau mulut. Contoh penyakit ini adalah sifilis, herpes, gonorrhea, AIDS, dan lainnya. STD disebabkan oleh berbagai jenis agen infeksi, seperti bakteri, virus (baik virus yang memiliki asam nukleat DNA atau RNA), jamur dan parasit. Penyakit ini dapat menimbulkan akibat yang cukup serius bahkan dapat menyebabkan kematian. Salah satu penyakit menular tersebut adalah AIDS, penyakit yang cukup mudah cara penularannya dan memiliki dampak yang berbahaya. Berdasarkan hal tersebut, penulis memilih membahas tentang AIDS. ${ }^{1}$

\section{Acquired Immuno - Deficiency Syndrome (AIDS) adalah penyakit} yang tidak asing lagi di telinga kita, yang mudah ditemui di setiap negara tanpa terkecuali. Penyakit ini sudah menjadi masalah yang cukup signifikan di negara berkembang, salah satunya Indonesia. Penyebab AIDS adalah infeksi yang disebabkan oleh Human Immunodefisiensi Virus (HIV). Pada awalnya, penderita yang terinfeksi HIV tidak menyadari bahwa mereka terinfeksi virus tersebut, tetapi mereka akan menyadarinya ketika sistem imun menurun. Kondisi ini menyebabkan mereka mudah diserang penyakit lainnya dan berakhir pada AIDS. Hal ini disebabkan karena HIV membutuhkan waktu yang cukup lama untuk menyerang sistem imun penderita. Selain itu, penderita yang terinfeksi HIV tidak tampak perbedaan yang signifikan dengan orang yang normal, baik warna kulit, suhu tubuh, denyut nadi, dan lainnya. Pen- derita baru bisa mengetahui kalau dia terinfeksi HIV jika dia diperiksa di rumah sakit atau di laboratorium. ${ }^{2}$

HIV terbagi atas dua tipe, yaitu HIV-1 dan HIV-2. Penderita AIDS pada umumnya terinfeksi oleh HIV-1. HIV-2, yang ditemukan pada tahun 1986, endemik pada wilayah Afrika Barat dan jarang ditemukan pada wilayah lain. HIV-1 dan HIV-2 serupa dari segi morfologi dan tipe infeksinya. Perbedaan yang mencolok dari kedua tipe HIV ini adalah HIV-1 lebih reaktif dari HIV-2. Selain itu, antigen yang reaktif terhadap core protein HIV-1 tidak reaktif terhadap core protein HIV-2, begitu pun sebaliknya. Perbedaan lainnya adalah HIV-1 merupakan tipe yang lebih virulen dan merupakan penginfeksi yang umum pada penderita AIDS seluruh dunia dibandingkan dengan HIV-2 yang terkonsentrasi pada wilayah Afrika Barat. Oleh karena itu, penulis memilih membahas HIV-1 yang menjadi penyebab utama dari penyakit AIDS di dunia. ${ }^{3}$

Setiap tahun, jumlah penderita AIDS bertambah banyak dan semakin didominasi oleh kalangan remaja. Kementerian Kesehatan Republik Indonesia mencatat jumlah penderita HIV dan AIDS rata-rata meningkat. Tahun 2011 sebanyak 21.031 kasus, 2012 sebanyak 21.511 kasus dan tahun 2013 sampai bulan Maret sebanyak 5.369 kasus. Jumlah kumulatif infeksi HIV yang dilaporkan sampai dengan Maret 2013 sebanyak 103.759. Data yang diperoleh mengenai jumlah penderita AIDS, tahun 2011 sebanyak 7.004 kasus, tahun 2012 sebanyak 5.686 kasus dan pada tahun 2013 sampai bulan Maret sebanyak 460 kasus. Jumlah kasus HIV di daerah Sumatera Barat pada tahun 2011 sebanyak 132 kasus, tahun 2012 sebanyak 133 kasus dan tahun 2013 sampai bulan Maret sebanyak 
38 kasus. Jumlah kumulatif infeksi HIV di Sumatera Barat sampai bulan Maret mencapai 739. Data yang diperoleh mengenai jumlah penderita AIDS di Sumatera Barat, tahun 2011 sebanyak 130 kasus, tahun 2012 sebanyak 120 kasus dan tahun 2013 sampai bulan Maret tidak ada (0). Jumlah kumulatif penderita AIDS sampai Bulan Maret tahun 2013 sebanyak 802 kasus. ${ }^{4,5}$

Berdasarkan data tersebut, dapat disimpulkan bahwa HIV-1 adalah suatu ancaman yang sangat potensial dalam penyebaran penyakit menular seksual. Mengetahui keberadaan HIV di dalam tubuh yang terinfeksi sedini mungkin merupakan hal yang penting agar dapat terhindar dari penyebaran transmisi virus ke tubuh orang lain dan antisipasi dalam kesulitan penanggulangannya. Dengan demikian, penulis berpikir diperlukan sebuah diagnosa dini yang lebih unggul dalam efektivitas dan sensitivitas untuk mengetahui keberadaan virus tersebut di dalam tubuh penderita.

\section{Diagnosa terbaru yang penulis bahas adalah diagnosa Double-} Protein Detect yang merupakan kombinasi antara tes yang mendeteksi antigen p24 (protein) dengan tes yang dapat mendeteksi enzim (protein) yang berasal dari HIV (reverse transkriptase, integrase, dan protease). Diagnosa ini merupakan salah satu jenis rapid test. Penulis mengusulkan kombinasi ini karena dapat meningkatkan validitas, efektifitas, dan dapat menghemat biaya tes. Alasan penulis tidak menggunakan metode tes yang mendeteksi respon antibodi (menghitung jumlah sel CD4+ seperti tes serologi) dikarenakan respon antibodi atau penurunan jumlah sel CD4+ dapat terjadi akibat infeksi selain HIV, contohnya infeksi virus Hepatitis B. Selain itu, tes tersebut memiliki validitas yang rendah, waktu yang dibutuhkan cukup lama, serta harus diikuti dengan tes antigen dan tes amplifikasi, sehingga dapat disimpulkan kurang efektif. Pembahasan tentang diagnosa Double-Protein Detect ini akan dijelaskan pada pembahasan.

Selain diagnosa Double-Protein Detect penulis menyarankan untuk melakukan tes NASBA (Nucleat Acid Sequence Based Amplification), sejenis tes amplifikasi berdasarkan urutan asam nukleat yang memiliki validasi tinggi dan merupakan metode terbaru setelah RT-PCR (Reverse Transcriptase Polymerase Chain Reaction). Penulis menyarankan agar tes NASBA dilakukan setelah melakukan tes Double Detect Protein, mengingat pentingnya follow up untuk memastikan keberadaan HIV pada tubuh penderita. Alasan lainnya adalah karena pentingnya menutupi kekurangan dari satu tes dengan tes lainnya sehingga dapat memperoleh hasil yang maksimal.

\section{METODE}

Artikel ini ditulis berdasarkan hasil penelusuran dan tinjauan kepustakaan mengenai fakta dan hal yang belum terpecahkan terkait jenis diagnosa HIV-1 yang lebih efektif dari diagnosa yang sebelumnya sebagai diagnosa dini. Penelusuran ditekankan pada bukti yang menunjukkan jenis-jenis diagnosa HIV-1 dan membuat jenis diagnosa yang lebih efektif.

\section{HASIL DAN PEMBAHASAN}

\section{Pengertian HIV}

HIV adalah virus jenis retrovirus yang memiliki asam nukleat berupa RNA dan memiliki enzim RNA-directed DNA polymerase (Reverse 
Trancriptase) untuk memproduksi hibrid DNA di dalam sel inang yang menyebabkan penyakit AIDS. HIV juga memiliki protein inner core dengan dua rantai RNA yang identik, dikelilingi oleh selubung protein atau kapsid dan sebuah envelope yang terdiri dari glikoprotein. ${ }^{3}$ Virus ini menyerang sistem kekebalan tubuh manusia sehingga virus, jamur, bakteri dan parasit mudah masuk dan menginfeksi tubuh. HIV pada umumnya menyerang sel CD4+ yang menjadi faktor pengikat dengan sel inang yang terinfeksi. Selain itu, HIV juga menyerang sel dendritik dan makrofag untuk memperbanyak reservoirnya.

Penularan HIV dapat terjadi melalui cairan tubuh yang terinfeksi seperti hubungan seksual, penggunaan jarum suntik terkontaminasi, transfusi darah atau diturunkan dari ibu yang terinfeksi HIV kepada anaknya. $^{3,6}$

\section{Gen-Gen Utama Pada HIV-1}

Seperti yang telah dibahas diatas, HIV-1 memiliki 3 gen utama yaitu gen gag, pol, dan env. Ketiga gen tersebut memiliki fungsi masingmasing. Gen gag berfungsi mengatur proses replikasi virus dan protein struktural, gen pol berfungsi mengkode enzim-enzim yang dibutuhkan untuk proses replikasi virus, dan gen env berfungsi mengatur pembentukan envelope (glikoprotein membran) HIV. Selain ketiga gen tersebut, terdapat gen-gen lain yang berfungsi mengatur proses transkripsi $\mathrm{HIV}^{7}$

\section{Aktivitas HIV}

HIV-1 memiliki beberapa faktor penting yang berkontribusi untuk mem-perbanyak dirinya agar dapat bertahan di dalam sel inang ketika terjadi respon sistem imun. Virus meningkatkan kecepatan replikasi untuk menghasilkan sejumlah besar partikel virus yang diproduksi per unit waktu. Selain itu, waktu generasi virus dinilai lebih singkat, yaitu saat membentuk pelepasan virion sampai menginfeksi sel baru, telah diperkirakan sekitar 2 hari. Dalam dua hari replikasi virus dapat mencapai jumlah kurang lebih 109 virus. Keadaan ini diikuti dengan kesalahan yang dimunculkan oleh enzim RT (Reverse Transcriptase), sehingga dapat menghasilkan populasi virus dalam sel inang yang terdiri dari kelompok virus terkait genetik tetapi tidak identik dan menimbulkan kemungkinan adanya substitusi yang mungkin dalam populasi virus itu. ${ }^{8}$

\section{Imunologi HIV}

Imunitas yang bereaksi pada HIV umumnya sama dengan respon imun pada virus lainnya dan menyerang kebanyakan virus yang ada dalam darah dan sirkulasi sel $T$. Meskipun target utama infeksi HIV adalah sel $\mathrm{T}$ CD4+, namun monosit, makrofag dan sel dendritik (misalnya sel Langerhans) yang mengekspresikan CD4+ serta kemokin koreseptor juga menjadi target dari infeksi HIV. Hal ini dikarenakan HIV memperbanyak reservoirnya melalui sel-sel tersebut. Penyimpangan kinerja sistem imun dapat terjadi karena infeksi oleh HIV, contohnya penurunan jumlah sel T CD4+ pada tubuh, hypergammaglobulinemia (peningkatan level sirkulasi antibodi), dan kapasitas fagositosis yang menurun. Penurunan populasi sel $\mathrm{T}$ CD4+ sangat berbahaya bagi sistem imun. Peran utama sel T CD4+ adalah sekresi sitokin, sebuah protein yang diperlukan pada hampir semua aspek dari sistem kekebalan tubuh. ${ }^{9}$

\section{Biologi Molekuler HIV}

HIV-1 memiliki struktur virion yang terdiri dari inti nukleokapsid dan envelope. Pada inti nukleokapsid 
terdapat dua salinan genom virus (ssRNA), protein inti (core protein) dan enzim reverse transcriptase. Lain halnya dengan envelope, virion dibagi menjadi dua bagian, yaitu lipid seluler dan protein virus bagian envelope. ${ }^{11}$ Molekul-molekul ini secara bersamaan memungkinkan virus untuk menginfeksi sel-sel sistem kekebalan tubuh dan mengontrol mereka untuk membangun salinan baru dari HIV. Setiap molekul dalam HIV berperan dalam proses ini dari langkah pertama lampiran virus untuk proses akhir budding. ${ }^{10,11}$

\section{Enzim Virus}

Enzim-enzim yang terdapat pada virion HIV-1 adalah reverse transkriptase, integrase, dan protease. Reverse transkriptase membangun salinan DNA dari genom RNA virus, yang kemudian digunakan untuk membangun virus baru. Enzim ini terikat pada RNA virus dan mulai membangun untai DNA yang pertama. Kemudian, enzim menghancurkan RNA dan membangun untai DNA yang kedua. Integrase mengambil salinan DNA dari genom virus dan memasukkan ke dalam genom sel yang terinfeksi. Dengan cara ini, HIV dapat laten dalam sel selama beberapa dekade, sehingga sangat sulit untuk memberi perlawanan dari antibodi. Protease HIV sangat penting untuk pematangan partikel HIV. Protein dalam HIV dibangun sebagai poliprotein yang panjang, yang kemudian harus dibelah menjadi potongan-potongan fungsional yang cocok dengan protease HIV. ${ }^{10}$

Secara umum, diagnosa HIV akan melewati jenis-jenis tes berikut:

\section{Rapid Test}

Rapid test adalah tes yang digunakan untuk mengetahui secara cepat ada atau tidaknya HIV di dalam tubuh kurang lebih dalam waktu 20 menit dan digunakan sebagai tes skrining. Rapid test membutuhkan sampel darah atau cairan mulut untuk mendeteksi adanya antibodi dan HIV. Tes ini dapat memberikan hasil yang salah jika immunoassay berada dalam window period (waktu setelah exposure tetapi sebelum tes menemukan antibodi). Tes immunoassays yang memberikan hasil positif akan menjalani follow up test.

\section{Follow up Test}

Follow up test adalah serangkaian tes yang digunakan untuk memperkuat sekaligus membuktikan kebenaran dari hasil rapid test. Tes ini meliputi sebuah tes diferensiasi antibodi yang membedakan HIV-1 dengan HIV-2, tes asam nukleat HIV1 yang mengidentifikasi virus secara lang-sung, atau Western Blot yang bisa juga digantikan dengan tes immunofluoresence assay yang mendeteksi antibodi. Tingkat akurasi rapid test ini sangat tinggi dan hampir tidak ada kesalahan. Follow up test dimaksudkan untuk memperkuat hasil rapid test, sehingga minim adanya kekeliruan diagnosa. Biasanya kesalahan ditemukan jika tes dilakukan selama window period. ${ }^{20}$

\section{RNA test}

RNA test akan mendeteksi virus secara langsung (kebalikan dari antibodi terhadap HIV) dan hal ini yang menguntungkan karena dapat mendeteksi HIV dalam waktu 10 hari setelah infeksi segera setelah muncul dalam aliran darah, sebelum pembentukan antibodi. Biasanya tes ini jarang digunakan karena membutuhkan lebih banyak biaya dibandingkan tes lainnya. 


\section{Tes Antigen p24}

Sebelum Kombinasi Seperti yang telah dijelaskan, HIV memiliki sebuah antigen yang khas yaitu protein virus yang disebut p24, protein struktural yang membentuk sebagian besar dari inti virus HIV atau bisa disebut kapsid. Tingginya kadar p24 yang hadir dalam serum darah dari orang yang baru terinfeksi selama periode singkat antara infeksi dan serokonversi, membuat tes antigen p24 berguna dalam mendiagnosis infeksi HIV primer.

Untuk mendapatkan hasil tes yang sempurna, protein virus p24 harus dalam keadaan baik berdasarkan aktifitas HIV, yang diukur menurut sensitivitas dan akurasi. Terdapat beberapa cara untuk meningkatkan sensitifitas tes antigen p24 diantaranya adalah modifikasi sederhana dari penggunaan penyangga untuk melisis virus agar lebih efisien, modifikasi sederhana energi panas yang digunakan untuk metode deteksi dengan cara pemisahan antibodi dan antigen, serta modifikasi sinyal tiramid dari amplifikasi.

\section{Diagnosa Dini pada Infeksi HIV de- ngan Menggunakan Tes Double-de- tect Protein}

Diagnosa dini pada kasus infeksi HIV merupakan diagnosa yang membantu mendeteksi keberadaan HIV pada masa awal infeksi hingga masa serokonversi. Diagnosa dini infeksi HIV terdiri dari beberapa tes, terutama rapid test. Hal ini disebabkan selain hasilnya bisa didapatkan dengan cepat, rapid test juga memilki validitas yang tinggi, tetapi harus memperhatikan fase yang sedang dijalani oleh pasien yang ingin menjalani tes tersebut. Caranya adalah dengan mengenali gejala-gejala awal yang dirasakan oleh pasien sebelum masa serokonversi karena pada masa serokonversi infeksi HIV tidak menunjukkan gejala apapun yang disebabkan oleh latennya virus di dalam tubuh.

Kombinasi dari tes yang mendeteksi antigen p24 dan tes yang mendeteksi enzim HIV-1 penulis namakan sebagai Double-Detect Protein. Pemberian nama ini dikarenakan tes antigen p24 merupakan tes yang mendeteksi antigen yang struktur molekulnya berupa protein, juga tes yang mendeteksi enzim HIV memiliki struktur molekul berupa protein. Kedua protein ini berasal dari virus sehingga gabungan dari kedua tes ini menguatkan diagnosa keberadaan virus. Metode tes Double-detect Protein ini dilakukan dengan cara mengambil serum darah dari pasien yang ingin melakukan tes. Pengambilan sampel dari serum darah adalah cara yang paling mudah dan paling efisien karena keberadaan HIV dapat dideteksi bersamaan dengan keberadaan sel T CD4+ sebagai faktor antibodi yang penting dalam tubuh. tes ini diharapkan dapat mendeteksi keberadaan virus yang juga terdapat di dalam serum pasien.

Metode tes Double-Detect Protein adalah mengambil serum darah pasien yang ingin dites, kemudian dilakukan pengasingan pada kedua protein ini dengan menggunakan kit yang compatible untuk kedua jenis protein tersebut. Selanjutnya dideteksi menggunakan pemeriksaan lainnya. Karena protein ini jenisnya berbeda, maka untuk menyatukannya dalam satu metode deteksi harus disesuaikan dengan suhu yang dipakai karena ada kemungkinan terdapat perbedaan pada suhu denaturasi dan suhu optimal pada masing-masing protein. Selain suhu, yang dibutuhkan untuk penyesuaian setelah serum diambil adalah $\mathrm{pH}$ (derajat keasaman). Kadar $\mathrm{pH}$ yang diatur sedemikian rupa akan 
mengoptimalkan proses kedua tes ini. Faktor penting lainnya adalah kit atau alat yang digunakan untuk mendeteksi kedua jenis protein ini, perlu dibuat kit yang baru yang dapat mendeteksi antigen p24 sekaligus tiga jenis enzim yang terdapat di dalam virus yaitu reverse transkriptase, integrase, dan protease.

Hal penting yang diperhatikan sebelum menggabungkan kedua tes tersebut menjadi tes Double-detect Protein adalah persamaan yang terdapat dalam struktur molekular yang ada pada protein antigen p24 dengan protein yang ada pada ketiga enzim HIV. Hal ini akan mempermudah pembuatan kit yang baru untuk medeteksi kedua jenis protein ini. ${ }^{23}$ Namun, gagasan penulis ini masih dalam bentuk rencana karena untuk mengetahui struktur protein yang ada pada antigen dan yang ada pada enzim membutuhkan penelusuran lebih lanjut berikut dengan penelitian untuk menunjang data-data yang diperlukan.

Selain itu dibutuhkan pengumpulan informasi mengenai perbedaan struktur pada kedua protein ini yang menyebabkan mereka tidak dapat disatukan pada hal tertentu, tentunya hal ini juga dibutuhkan penelurusan dan penelitian lebih lanjut. Untuk lebih lanjut akan dapat disimpulkan tentang faktor yang cocok dan tidak cocok pada kombinasi deteksi kedua protein ini. Jika terlalu banyak ketidakcocokan dikarenakan protein inti seperti p24 dan ketiga enzim pada HIV, maka diusahakan pada penelusuran penelitian tersebut untuk lebih fokus pada hubungan antara antigen p24 dengan enzim reverse transkriptase. Hal ini disebabkan karena enzim ini merupakan enzim utama yang bertanggung jawab dalam merubah RNA pada HIV menjadi DNA hingga menyusup ke dalam sel inang, dan berperan se- bagai faktor poliferasi yang penting bagi HIV.

Alasan penulis memilih kombinasi antara tes mendeteksi antigen p24 dengan tes yang mendeteksi enzim karena antigen p24 sendiri adalah suatu protein inti yang khas yang berasal dari HIV sedangkan enzim reverse trankriptase, integrase, dan protease merupakan protein inti yang khas dari HIV. Sehingga dengan adanya pendeteksian kedua unsur dari virus ini akan menguatkan keberadaan dari virus. Namun untuk menutupi kelemahan tersebut, penulis menyarankan untuk melakukan followup test yaitu tes NASBA yang merupakan tes amplifikasi berdasarkan urutan asam nukleat yang memiliki validitas yang tinggi, murah, efisien dan tidak memilki batasan fase yang dialami oleh tubuh yang terinfeksi HIV. Berikut penulis akan bahas tentang tes NASBA.

\section{Tes NASBA Sebagai Follow Up Test}

Amplifikasi urutan asam nukleat berbasis (NASBA) adalah metode dalam biologi 24 molekuler yang digunakan untuk memperkuat urutan RNA. NASBA dikembangkan oleh $J$ Compton pada tahun 1991, yang didefinisikan sebagai "teknologi tergantung primer yang dapat digunakan untuk amplifikasi asam nukleat secara terus-menerus dalam campuran tunggal pada satu suhu." Segera setelah penemuannya, NASBA digunakan untuk diagnosis cepat dan kuantifikasi HIV-1 dalam serum pasien. Meskipun RNA juga dapat diperkuat dengan PCR, keuntungan utama NASBA adalah bahwa ia dapat bekerja pada kondisi isotermik, biasanya pada suhu konstan $41^{\circ} \mathrm{C}$. NASBA telah diperkenalkan ke bidang kedokteran dan telah terbukti memberikan hasil yang lebih cepat dari PCR, selain itu juga dapat menjadi lebih sensitif.$^{12}$ 


\section{SIMPULAN}

Berdasarkan pembahasan atas gagasan yang dikaji, kami menyimpulkan beberapa hal. Diagnosa dini pada infeksi HIV merupakan diagnosa yang dapat membantu pendeteksian HIV pada fase awal infeksi hingga sebelum masuknya fase serokonversi. Pada saat inilah tes Double-detect Protein dapat dilakukan. Namun, perlu dilakukan tes NASBA untuk mengkonfirmasi hasil tes Double-detect Protein untuk mengantisipasi ketidakoptimalan hasil yang diperoleh.

Tes Double-detect Protein kemungkinan memiliki keefektifan lebih tinggi dari tes yang mendeteksi antigen p24 ataupun tes yang mendeteksi antidbodi.

Mekanisme tes Double-detect Protein adalah dengan cara mengambil serum pasien yang ingin dites, kemudian dilakukan pengasingan antigen yang berupa p24 dan enzim dengan menggunakan alat yang kompatibel pada struktur molekul dari kedua protein tersebut.

\section{DAFTAR RUJUKAN}

1. Hubach RD, Dodge B, Davis A, Smith $A D$, Zimet GD, Van Der Pol B. Preferred methods of sexually transmitted infection service delivery among an urban sample of underserved midwestern men. Sex Transm Dis. 2014 Feb;41(2):129-32

2. Mendoza $\mathrm{Y}$, Bello $\mathrm{G}$, Castillo $M$ J, Martínez AA, González C, GarcíaMorales C, Avila- Ríos S, Reyes-Terán G, Pascale JM. PLoS One. 2014 Jan 13;9(1): e85153

3. Stevens CD. Clinical immunology and serology. 2th ed. North Carolina: F. A. Davis Company; 2003.

4. Dirjen Pengendalian Penyakit dan Penyehatan Lingkungan. Laporan perkem- bangan HIV-AIDS triwulan I. 17 Mei 2013; hal 1-2

5. Dirjen Pengendalian Penyakit dan Penyehatan Lingkungan. Laporan perkembangan HIV-AIDS triwulan I. 17 Mei 2013;hal 11-16

6. Baratawijaya KG. Imunologi dasar. 8th ed. Jakarta: Balai Penerbit FKUI; 2009.

7. Wibowo HA, Setiawaty V, Salwati E. Epidemology molekuler genotype HIV-1 pada orang dengan AIDS. Bul. Penelit. Kasehat. 2011;39(1):1-9

8. Berry IM.Genetic aspect of HIV-1 evolution and transmission. Stockholm: Karolinska Instutet; 2008.

9. Stanley J. Essentials of immunology and serology. West Indies: Thomson Delmal Learning; 2002.

10. RCSB. The structural biology of HIV. Protein data bank. 2011

11. Jia $X$, Singh $R$, Homann $S$, Yang $H$, Guatelli J, Xiong Y. Structural basis of evasion of cellular adaptive immunity by HIV-1 Nef. Nat Struct Mol Biol. 2012 Jun 17;19(7):701-6.

12. Schneider P, Wolters L, Schoone G, Schallig $H$, Sillekens $P$, Hermsen, $R$. Real-time nucleic acid sequence-based amplification is more convenient than real-time PCR for quantification of Plasmodium falciparum. J clin microbiol. 2005;43 (1): 402-5 